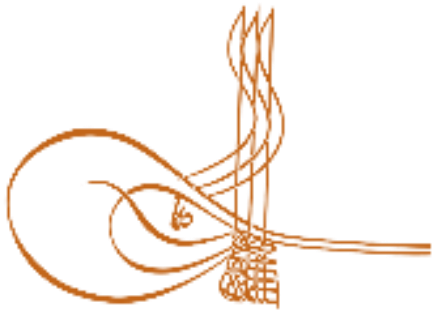

www.turkishstudies.net/social
Turkish Studies - Social Sciences

eISSN: $2667-5617$

Research Article / Araştırma Makalesi

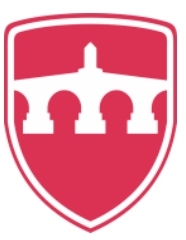

INTERNATIONAL

BALKAN

UNIVERSITY

Sponsored by IBU

\title{
Kentin Değişen Yüzünde Ankara Mahmut Paşa Bedesteni
}

Ankara Mahmut Paşa Bedesten on the Changing Face of The City

\author{
Sena Işıklar Bengi - Özlem Sağıroğlu**
}

\begin{abstract}
The cities are transformed with the flowing time. The transformation of cities is seen in many physical, social and cultural ways. These elements can be viewed individually, but also seen as intertwined formations that trigger each other. The dynamic structure of the users, which is the most important element of cities, supports this multi-faceted change. In this study, the transformation of The Ankara Mahmut Paşa bedesten, one of the bazaar structures in the core of the city, which hosts the economic and social and administrative elements of Ottoman cities, into an Anatolian Civilization Museum, which has a function of displaying and protecting artistic products in a metropolis that changes its cultural, social, economic and administrative form. Within the scope of the study, the contribution of the bedesten to the city was presented, then the city's texture and its contribution when building as built and the present time were conveyed. Through literature researches and on-the-spot observations, the time-varying spatial status and usage relations in the city were revealed in the context of the Mahmut Paşa Bedesten/ Museum of Anatolian Civilizations. As a result, it is understood The Anatolian Civilizations Museum enables it to work as a social glue that attracts visitors with this transformation. Bedesten became a place open to all while addressing only the commercial sector of the society, it has included the public open use with its open spaces designed around it, and has arranged the open area to provide space for changing public uses.
\end{abstract}

Structured Abstract: One of the social, human and economic activities taking place within the city is commercial activities. In history, the commercial activities was carried out in bazaars and bedestens, one of the main places in the cities. This type of building was located in the heart of the city and was effective in the mention of the settlement as a city. The commercial shops around it have strengthened its function with structures that include various economic and social functions such as inns, Turkish baths, mosques, and hospitals. Bedesten has been effective in creating safe trade conditions by gathering traders and artisans within the structure. It has also been presented in earlier studies that bedestens in Ottoman cities had social functions as well as economic functions. Buildings such as the bedesten, shops, inns, baths, mosques and hospitals, which define the city center, have mostly not reached the present day due to lack of maintenance or due to disasters

\footnotetext{
* Arş. Gör., Gazi Üniversitesi, Mimarlık Fakültesi, Mimarlık Bölümü Res. Asst., Gazi University, Faculty of Architecture, Department of Architecture ORCID 0000-0002-1554-5981

sena.isiklar@gmail.com

** Doç. Dr., Gazi Üniversitesi, Mimarlık Fakültesi, Mimarlık Bölümü

Assoc. Prof. Dr. Gazi University, Faculty of Architecture, Department of Architecture

ORCID 0000-0001-6708-3208

osagiroglu@gazi.edu.tr

Cite as/ Atıf: Işıklar Bengi, S., Sağıroğlu, Ö. (2020). Kentin değişen yüzünde Ankara Mahmut Paşa Bedesteni, Turkish Studies - Social, 15(3), 1165-1183. https://dx.doi.org/10.29228/TurkishStudies.40626

Received/Geliş: 18 January/Ocak 2020

Accepted/Kabul: 25 April/Nisan 2020

Checked by plagiarism software

Copyright $(\subset$ INTAC LTD, Turkey

Published/Yayın: 30 April/Nisan 2020

CC BY-NC 4.0
} 
such as fire and earthquakes. But some of them still exist and has a role in comtemporary world today, due to functional changes. One of these examples is Mahmut Paşa Bedesten in Ankara. Mahmut Paşa Bedesten in Ankara was built in 1451. It was a building that attracted attention for more than 500 years lost its importance in the early 19th century. It had a fire disaster with Kurşunlu Han, which was built by Mahmut Paşa on the same date and located in the north-east of the building. These two structures were repaired and refunctionalized with restoration during the Republican Period. They are used as the Museum of Anatolian Civilizations today. In this study, the transformation of Ankara Mahmut Paşa Bedesten into the Museum of Anatolian Civilizations is examined. The building is documented and the spatial and usage-related relations that have changed over time have been revealed in the case of Ankara Mahmut Paşa Bedesten.

Mahmut Paşa Bedesten was located next to Ankara Castle in the 15th century. In addition to being the center point, this area also constitutes the commercial area of the city. Around 16th and 17th century Suluhan, Tuz Hanı, Un Kapanı Han, Safran Han, Yeni Han, Çukur Han, Çengel Han, Pilavoğlu Han, Pembe Han, Bakır Han, Kıbrıs Han, Pirinç Han and artisan bazaars added to the area and strengthened the commercial function of the region. All of these structures show the commercial value and central importance of the place in which the bedesten is located. It is also thought that these spaces contain social and administrative tasks. However, in the city, which has transformed over time, the bedesten, inns, and markets where commercial activities took place in the past have been replaced by shopping malls, accommodation-owned inns have been replaced by hotels, and manufacturing inns have been replaced by facilities in industrial areas.

After the declaration of the Republic, the city administration and urban planning have developed in a way to focus on conservation. In 1935, Atatürk accelerated the conservation movements and reported the need to repair the old works. Thus, the buildings from the Ottoman Empire were transformed to reflect the new identity of the country. In this context, Tarsus Kırkkaşık, Sandal, Zincirli, Kayseri, Gaziantep Bedestens tourist to cover trade; Vezirköprü, Yusuf Paşa, Uşak, Tekirdağ, Afyonkarahisar, Kastamonu, Bursa and Kütahya Bedestens to cover trade; Tire, Niğde, Manisa Rum Mehmet Paşa and Mahmut Paşa Bedestens have been change to cover cultural activities.

Ankara, which is designated as the capital of the Republic of Turkey, has been developed through planning studies. The region where Mahmut Paşa Bedesten is located is defined as old Ankara with the Jansen plan, which greatly influenced the development of the city. It is aimed to restore the region to accommodate commercial, touristic and cultural functions. Considering the necessity of exhibiting and preserving ancient artifacts, the idea of establishing a Hittite Museum was born. Accordingly, the plot of Mahmut Paşa Bedesten was chosen as a site where these works will be exhibited. Bedesten, undergoing transformation, has been transformed to the Museum of Anatolian Civilizations since 1968.

In the Anatolian Civilizations Museum, the cover coat of Mahmut Paşa Bedesten was repaired with original material and turned into an exhibition hall. The Kurşunlu Han, located next to the building, was added to the complex as the warehouse of the museum. While Kurşunlu Han, which constitutes the warehouse part of the museum, has a function that is closed to visitor use, the bazaar that constitutes the exhibition hall of the museum also reveals itself as a viewing object. The stone walls of the bazaar are used as a base for the display of archaeological remains, clay artifacts, sculptures, and pieces of jewelry. The domed interior of the bedesten offers a volume where stone works are exhibited and also used as a multi-purpose hall. The Anatolian Civilizations Museum enables it to work as a social glue that attracts visitors. Museum-cafe, resting areas, souvenir unit and open space arrangements are also located in the space and they attract the attention of users. Thus, with this transformation, bedesten became a place open to all while addressing only the commercial sector of the society, it has included the public open use with its open spaces designed around it, and has arranged the open area to provide space for changing public uses. In addition, the fact that the building is on a touristic route today seems to be encouraging in its use as a living space.

The city continues to expand over time and to create new centers. New spatial formations and new types of structures form because of the changing of public activities, human interactions, technological conditions, shopping practices of the old buildings, those whose new use is adopted by the city and who adapt to the new dynamics of the city continue to maintain its vitality. Transformation is inevitable in line with changing urban uses and spatial shaping. From this point on, with the development of historical awareness, other old works in the city should be protected, and the structural condition of the city should be criticized and brought to life in line with the changing uses.

Turkish Studies - Social, 15(3) 
Keywords: Transformation of cities, adaptive re-use, usage, bedesten, museum.

Öz: Kentler akıp giden zamanla birlikte dönüşmektedir. Kentlerin dönüşümü fiziksel, toplumsal, kültürel birçok yönden görülmektedir. Bu unsurlar tek tek izlenebildiği gibi aynı zamanda birbirini tetikleyen, birbirinin içine geçmiş oluşumlar olarak da görülmektedir. Kentlerin en önemli ögesi olan kullanıcıların dinamik yapısı, bu çok yönlü değişimi desteklemektedir. Bu çalışmada kentin dönüşen yapısı içinde yapıldı̆̆ı dönemde Osmanlı kentlerinin ekonomik ve sosyal ve idari unsurlarını barındıran, kentin çekirdeğinde yer alan bedesten yapılarından Ankara Mahmut Paşa Bedesteni'nin metropolleşen, kültürel, sosyal, ekonomik ve idari biçimi değişen bir kentte sanatsal ürünlerin sergilendiği, korunduğu, turistik bir fonksiyonu olan Anadolu Medeniyetler Müzesi'ne dönüşümü incelenmektedir. Çalışma kapsamında bedestenlerin kente katkıları sunulmuş, ardından Ankara Mahmut Paşa Bedesteni'nin yapıldığı dönem ve günümüz zamanında yer aldığı kent dokusu ve kente katkısı aktarılmıştır. Literatür araştırmaları ve yerinde gözlem çalışmaları aracılığıyla, kent içinde gerçekleşen zamanla değişen mekânsal durum ve kullanıma dair ilişkiler Ankara Mahmut Paşa Bedesteni/ Anadolu Medeniyetler Müzesi özelinde açı̆̆a çıkarılmıştır. Sonuç olarak, dönüşümle birlikte, Anadolu Medeniyetleri Müzesi Ankara'nın önemli ve büyük müzelerinden biri olarak turistik bölgede, sosyal tutkal olarak çalıştı̆̆ı anlaşılmaktadır. Bedesten eskiden, yalnızca toplumun bir kesimine (toptan ticaret yapanlar, kasa kullanımı ihtiyacı duyanlar gibi toplumun orta-üst kesimine) hitap ederken herkese açık bir yere dönüşmüş, çevresinde tasarlanan açık alanları ile kamusal açık kullanımını içine katmış, açık alanı değişen kamusal kullanımlara (Örn. gastronomik faaliyetler, her yaştan kullanıcının dinlenme ihtiyacı için oturma alanları, gruplar için buluşma eylemleri vb.) imkân sağlayacak şekilde düzenlenmiştir.

Anahtar Kelimeler: Kentlerin dönüşümü, Yeniden işlevlendirme, Kullanım, Bedesten, Müze.

\section{Bedesten yapıları ve kente katkısı}

Şehir coğrafyası kentsel mekânla ilgilidir. Kent fiziki bir çevre üzerine kurulu olmasına rağmen insan faaliyetleri ile şekillenmektedir. Ona yaşam katan sakinlerinin varlığı, davranışları, birbirleri ve yapılı çevre ile kurdukları iletişimleri sayesinde anlam kazanmaktadır (Işsılar, 2017). Kent içinde gerçekleşen sosyal, beşerî ve ekonomik ilişkileri belirleyen önemli faktörlerden biri ticari eylemlerdir. Ticari eylemler, yerleşik hayata geçilmeden göçebelerle yerleşikler arasında ve göçebelerin kendi aralarında ticaret yapması ile başlamış olsa da geniş çaxplı ticaret eylemi yerleşik alanlarda ve şehirlerde sürdürülmüştür (Cezar, 1985: 17,18). Bu eylemin gerçekleştiği başlıca tarihi mekânlardan biri bedestenlerdir.

Osmanlı kentinde merkezi öneme sahip ticari yapılardan biri olan Bedesten'in kelime kökeninin pamuk ya da keten dokuma anlamına gelen "bez" kelimesine dayandığı, kelimenin kumaş satıcısı anlamına gelen bazzaz kelimesini ve kumaşçılar çarşısı anlamına gelen "beziztan, bezzazistan" sözcüğünün elde edilmesini sağladığı Cezzar (1985) belirtilmektedir. Bu kelime 17.yy'a bedestan, günümüze ise bedesten olarak gelmiştir (Cezar, 1985: 13).

Bedesten önceleri tek bir ticaret yapısı, kumaşçılar çarşısının adı olarak anılırken, daha sonra Anadolu'da 13.yy'ın ikinci yarısından itibaren özel biçimde yapılmış ticaret yapılarının ismi olmuştur. Bedestenlerin özel bir yapı tipine bürünmesi ise 15yy'da Beylikler dönemi ile başlamıştır. Böylelikle bezzazlar toplu bir şekilde, sağlam bir yapı etrafinda toplanarak güvenli ticaret koşulları yaratılmıştır (Cezar, 1985: 14, 212). Osmanlılarda ise ilk bedesten Yıldırım Beyazıt tarafından Bursa'da yaptırılmıştır. Bu bedesten daha sonra yapılan diğer Osmanlı bedestenlerine örnek teşkil etmiştir (Aslanapa, 1986: 80). 


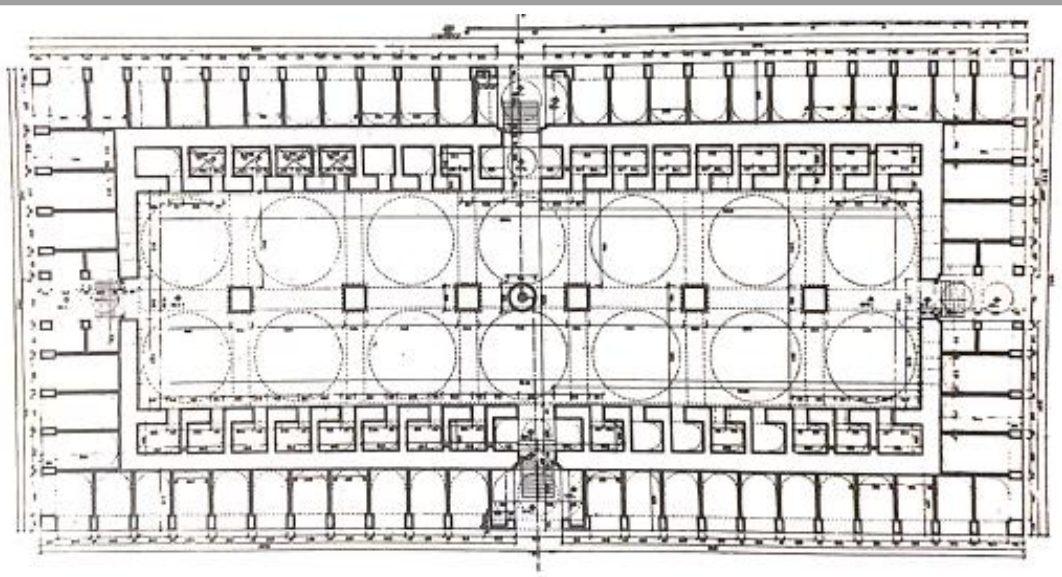

Şekil 1: Bursa bedesteni (Cezar, 1985: 221)

Bedestenler belli-başlı ticarî kolların, kuyumcuların, ipekçilerin, halıcıların, kumaşçıların, baharatçıların, aktarların ve kitapçıların bulunduğu bir merkez olarak kent yer almıştır (İntepe, 2005). İçerdiği bu birimler sebebiyle, çarşı-pazar ya da dükkânlar grubuyla karıştırılmamalıdır. Büyük ticaret merkezlerinde yer alan kuyumcu, kasa ve kumaş tüccarlarının ürünlerini sergilediği mekânların yapıda yer alması bu farklılığı yaratmaktadır.(Goodwin, 2012: 107). Yapının çevresinde ise günlük ihtiyaçların görüldüğü meyve, sebze, tahıl, un, tuz gibi gıda maddelerinin, odun-kömür gibi yakacak maddelerinin ticareti yapılmıştır (İntepe, 2005). Ayrıca toplumsal düzen içinde ekonomik ve sosyal işlevleri ile de önemli olmuştur (Cezar, 1985: 296). Bu işlevlerine ek olarak Osmanlı yaşamında bedestenler,

- Yarı-resmi ticaret mekânı olması,

- Devlet ve esnaf ilişkilerindeki belirleyici rolü,

- Kent içinde ticaret eylemlerinin gerçekleştiği düğüm noktalarını oluşturması,

- $\quad$ Mekânsal özellikleri sebebiyle maddi ve manevi yönlerden güvenli yerler olarak anılmas1,

- $\quad$ Para emanet haneleri gibi çalışması,

- $\quad$ Günümüz bankaları gibi maddi değerlerin takibinin yapıldığı yer olması,

- Bedestende ileri gelen kişilerin devlet işlerinde bilirkişi olarak görev yapması gibi nitelikleri ile büyük önem arz etmiştir (Cezar, 1985: 296-319).

Cezar (1985) bedestenleri mimari tipolojisi, iç mekân bölmeleri, dükkân düzenleri, bağımsız biçimlenişleri gibi unsurları temel alınarak 6 maddede sınıflandırmıştır:

1. Mahzenli bedesten: Osmanlı bedestenlerinin en eski türüdür. Bu tipte iç mekânda bölmeler sıralanmıştır (Cezar, 1985: 221).

2. Dışta dükkânlı bedesten: Bu bedestende iç mekânda mahzen ya da dükkân yer almamaktadır. Bütün dükkânlar dış mekânda yer alırken, iç mekân bölümlendirilmemiş bedesten aktivitesini içermektedir (Cezar, 1985: 249).

3. Arasta bedesten: $\mathrm{Bu}$ tip bedestenler arasta düzeninde inşa edilmiştir. Bir sokak üzerine konumlanan karşılıklı dükkân sıraları gibi bir düzenden meydana gelmektelerdir. Bazı arastaların boyları diğerlerine göre daha kısa olarak görülmektedir. (Cezar, 1985: 262). 
4. Arastalı bedesten: Arastalı bedestende yapılar arasta düzeninde bir çarşı ile birlikte tasarlamaktadır. Arasta ya yapının etrafinda ya da yapının yanında yer almaktadır (Cezar, 1985: 276).

5. Kat bedesten: Bazı bedestenler bağımsız yapılar olarak inşa edilmeyip, yapıların bir katına yerleşmiş şekilde çıkmaktadır (Cezar, 1985: 283).

6. Sade tek hacimli bedesten: Bu bedestenler tek bir hacimden oluşmaktadır. İçlerinde ve dışlarında mahzen ya da dükkân yapıları bulunmamaktadır. Çoğunlukla ticari eylemlerin yoğun olmadı̆̆ kentlerde varlık göstermektedirler (Cezar, 1985: 286).

Tablo 1: Tipolojilerine Göre Bedesten Örnekleri (Cezar, 1985: 221- 287)

\begin{tabular}{l|l} 
Bedesten tipolojisi & \multicolumn{1}{c}{ Örnek yapi } \\
\hline Mahzenli bedesten & $\begin{array}{l}\text { Bursa Bedesteni, Edirne Bedesteni, İstanbul Eski Bedesteni, İstanbul } \\
\text { Sandal Bedesteni, Galata Bedesteni, Tire Bedesteni }\end{array}$ \\
\hline Dişta dükkânlı bedesten & $\begin{array}{l}\text { Manisa Bedesteni, Tekirdağ Bedesteni, Merzifon Bedesteni, Kastamonu } \\
\text { Bedesteni }\end{array}$ \\
\hline Arasta bedesten & $\begin{array}{l}\text { Kütahya Bedesteni, Niğde Bedesteni, Kayseri Bedesteni, Isparta Firdevs } \\
\text { Bey Bedesteni, Kozan Bedesteni, Gümüşhacıöy Bedesteni, Gaziantep } \\
\text { Zencirli Bedesteni, Adana Bedesteni, Afyonkarahisar Bedesteni }\end{array}$ \\
\hline Arastalı bedesten & Ankara Mahmut Paşa Bedesteni, Vezirköprü Bedesteni, Tokat Bedesteni \\
\hline Kat bedesten & Erzurum Bedesteni, Bor Bedesteni \\
\hline Sade tek hacimli bedesten & $\begin{array}{l}\text { Bayburt Bedesteni, Amasya Bedesteni, Trabzon Bedesteni, Gelibolu } \\
\text { Bedesteni }\end{array}$ \\
\hline
\end{tabular}

Kentlerin kendine özgü ulu camileri olduğu gibi, kendilerine özgü de bedestenleri bulunmaktadır. Yerleşim yerindeki önemlerine bağlı olarak yaklaşık benzer modellerle kurgulanmışlardır (Goodwin, 2012: 415). Genellikle kare ya da dikdörtgen planlı, kubbeli ve kalın taş duvarlı mimari mekânlar olarak varlık göstermişlerdir. Şehrin merkezinde bir, iki veya dört ayrı kapısı bulunan bir kale gibi yükselmişlerdir (İntepe, 2005). Günümüzde Türkiye sınırlarında İstanbul'da 3 olmak üzere, Kütahya, Urfa, Kayseri, Edirne, Afyonkarahisar, Manisa, Maraş ve Gaziantep'in 2'şer bedesteni bulunmaktadır. Bursa Bolu, Trabzon, Şebinkarahisar, Lâdik, Tosya, Erzurum, Amasya, Bayburt, Erzincan Vezirköprü, Ankara, Konya, Zile, İnebolu, Bitlis, Van, Kırklareli, Tokat, Akhisar, Menemen, Aydın, Tire, Denizli, Nazilli, Milas, Antalya, Alanya, Tarsus, Adana, Sivas, Diyarbakır ve Tekirdağ'da da bedestenler bulunmaktadır (Cezar, 1985: 219).

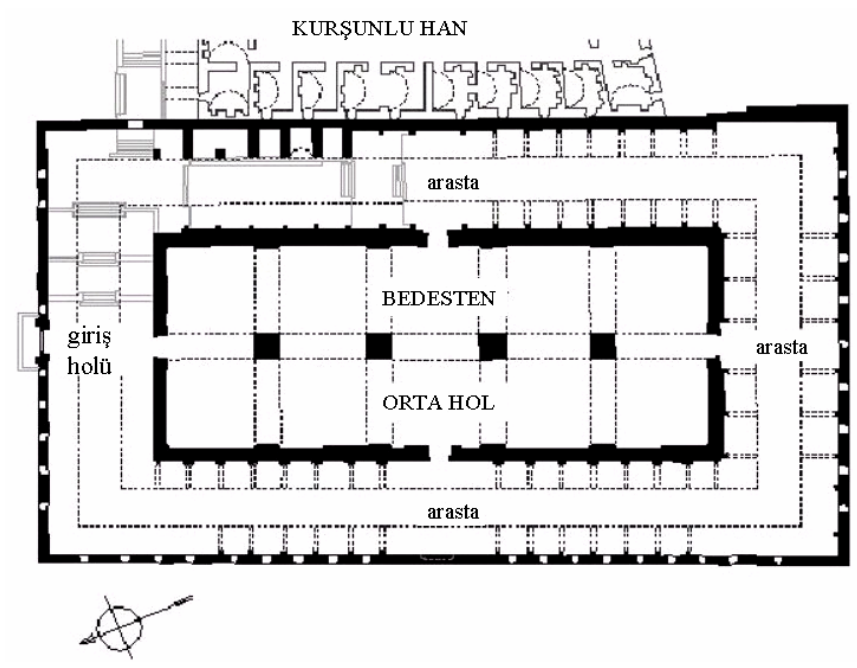

Şekil 2: Ankara Mahmut Paşa Bedesteni planı (Kurtay ve diğerleri, 2003) 

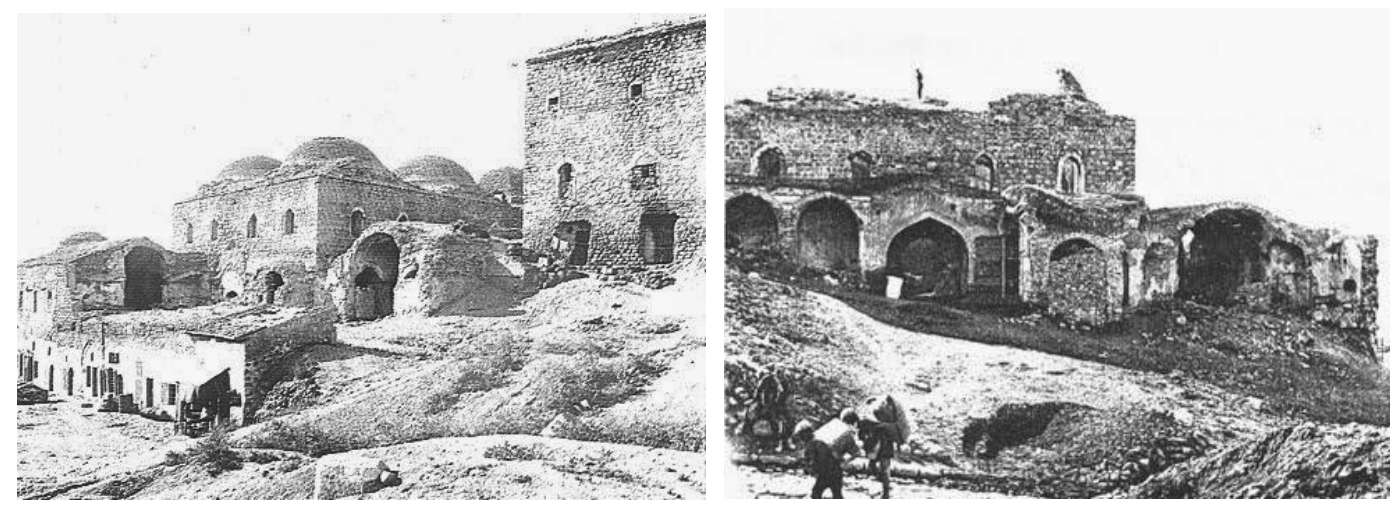

Şekil 3: 1930’larda Mahmut Paşa Bedesteni ve Kurşunlu Han'ın onarım öncesi durumu

(Tunçer, 2014)

Ankara'da bulunan Mahmut Paşa Bedesteni arastalı bedesten plan tipolojisinde olan, 1451 yılında tahta geçen Fatih Sultan Mehmet zamanında İstanbul, Bursa, Edirne, Amasya, Manisa ve Selanik gibi illerde yapılan imar çalışmaları kapsamında inşa edilen yapılar arasındadır (Cantay, 1988a: 69-74). Ankara'nın ticari merkezinin başlıca yapılarından biri olan bedesten, Atpazarı'nda, Hisar'ın güney-batısında yer almaktadır. Taci-zade Cafer Çelebi bedesten inşasının Fatih Sultan Mehmet'in Sadrazamı Mahmut Paşa tarafindan yaptırıldığı belirtilmiştir (Tunçer, 2014). Mahmut Paşa Bedesteni klasik dikdörtgen şemalı bedesten tipinde planlanmıştır. Cezar bu yapıyı arastalı bedestenler sınıfında ele almaktadır. Dört tarafı dükkânla çevrilmiş, bitişinde bir kervansaray yapısı olan bir bedestendir. Yanında yer alan Kurşunlu Han diye adlandırılan kervansarayda ise iç ticari mekânların yanı sıra dış cephelerden birinde de dükkânlar yer almaktadır. Üstü iki sıra düzeninde 10 adet kubbe ile örtülür. Üst örtü ayrıca dört adet paye ile taşınmaktadır (Cezar, 1985: 278-279). Bedesten, 19. yüzyıl başlarında sof endüstrisinin çökmesiyle önemini kaybetmiştir. Kuzeydoğusunda konumlanan aynı tarihlerde Mahmut Paşa tarafından inşa edilen Kurşunlu Han ile birlikte yangın felaketi geçirmiştir. 1881 yılındaki büyük yangının ardından yapının kullanım faaliyetleri durmuştur. 1916 yılında çıkan yangınla ise bölgede büyük tahribat oluşmuştur (Tunçer, 2014). Tahribatın ardından Mahmut Paşa Bedesteni Bedesten ve Kurşunlu Han Cumhuriyet Dönemi’nde onarılmışlardır. Restorasyon uygulaması ile yeniden işlevlendirilen yapılar günümüzde Anadolu Medeniyetleri Müzesi olarak kullanılmaktadır.

Osmanlı Devleti İpek Yolu'nun coğrafi avantajını kullanarak, dünya ticaretini 14. yüzyıldan 17. yüzyıla kadar elinde tutmuştur. Kentsel yerleşim alanlarında ticari hayatı geliştirmek ve yönlendirmek için çarşılar inşa ettirmiştir (İntepe, 2005). Kentin hayat damarları merkez çarşıda atmaktadır. Bu alanda toplumsal ilişkiler ve mimari beğeniler çarşının maddesel kültürünü oluşturmaktadır. (Cerasi, 1999: 115, 116). Günümüzde ise kent içindeki kamusal faaliyetler değişen insan etkileşimleri, teknolojik koşullar ve alışveriş pratikleri sebebiyle dönüşüme uğramıştır. $\mathrm{Bu}$ pratikler de kentsel mekânın fiziksel formunu etkileyerek farklı mekânsal biçimlenmeleri ve yeni yapı türlerini mimari oluşumlara katmıştır. Kent gittikçe gelişmiş, etki alanını genişletmiştir. Dolayısı ile eski yapılar ve anlamları kentin yeni form ve kullanımına denk düşecek şekilde dönüşmüştür. Bu çalışmada kentin dönüşen yapısı içinde Ankara Mahmut Paşa Bedesteni'nin Anadolu Medeniyetleri Müzesi'ne dönüşümü incelenmektedir. Çalışma ile dönüşen kentte ve günümüzde yapının yeri ve kullanım biçimi belgelenecektir. Böylece zaman içinde değişen mekânsal ve kullanıma dair ilişkiler Ankara Mahmut Paşa Bedesteni özelinde açığa çıkarılacaktır. 


\section{Ankara Mahmut Paşa Bedesteni’nin (1464-1471) inşası döneminde (15.yy) bulunduğu kent çevresi ile ilişkisi}

Aliağaoğlu ve Uğur'un (2016) aktarımına göre Osmanlı belgelerinde kent, "cuma k1lınır ve pazar durur yer" şeklinde tanımlanmıştır. Bu tanıma benzer şekilde Cezar da bir yerleşmenin şehir sayılmasında çarşının varlığının altını çizmektedir. Bu noktada işlevsel alanların kent içindeki önemi ve kenti biçimlendirmedeki etkileri anlaşılmaktadır. Ankara özelinde ise kentin merkezinde yer alan çarşıda bedesten, çevresinde ticari dükkânlar, han, hamam, cami ve hastane yer almıştır. Bu birimlerin konumlanmasında Selçuklu dönemi yollarının, ticaret aksları Hac Yolu, Basra Bağdat Yolu ve Tebriz'e ulaşan aksın katkısı olmuştur (Atalan, 2016).

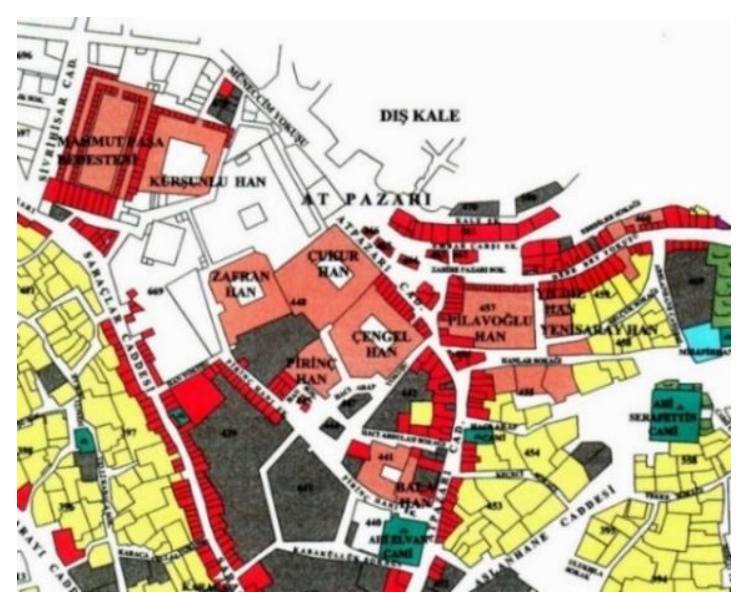

Şekil 4: Mahmut Paşa Bedesteni, Kurşunlu Han ve diğer vakıf hanları (1929 Tarihli

Ankara Kadastral Haritaları Kuyud-u Kadime Arşivi; Tunçer, 2014)

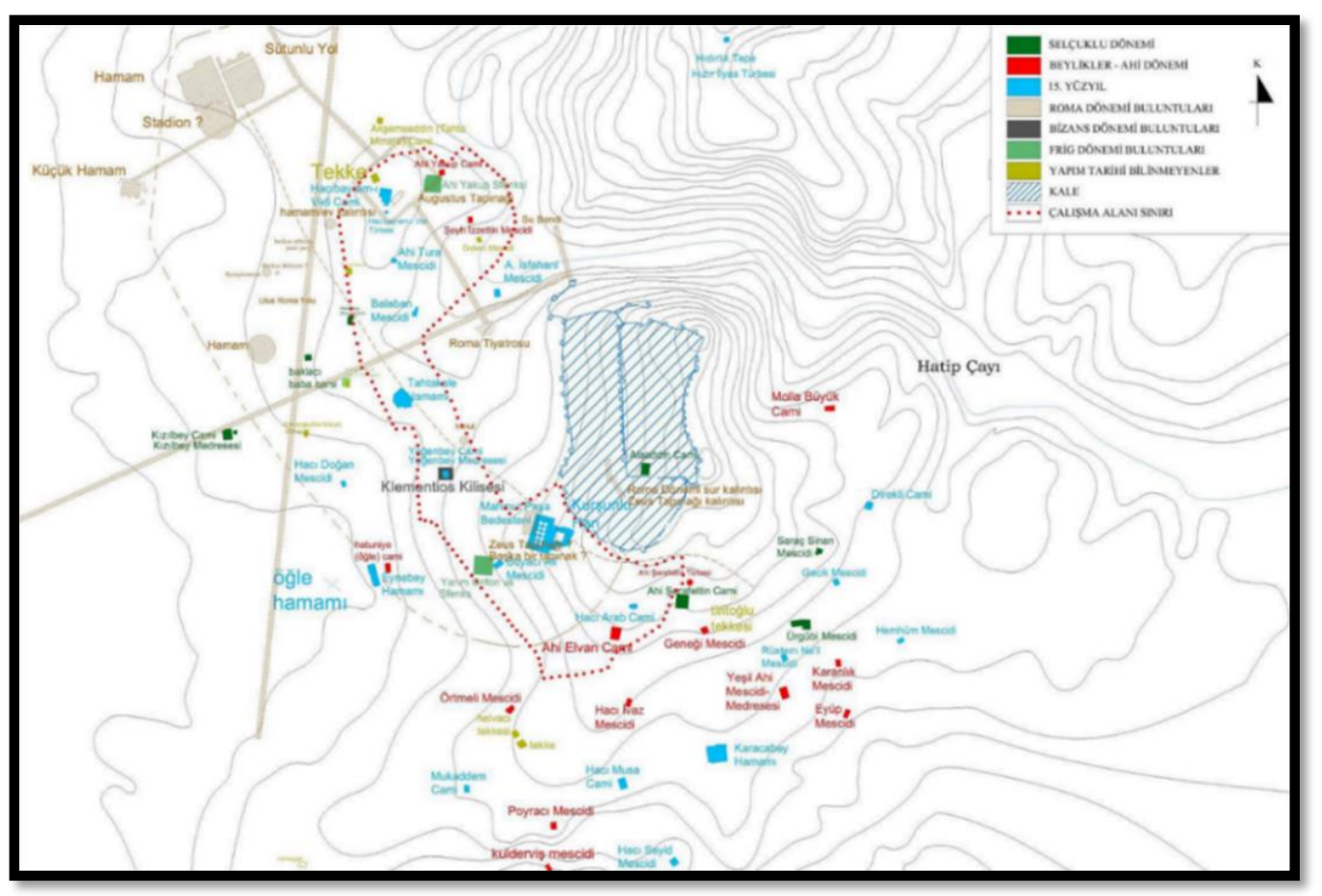

Şekil 5: 15. Yüzyılda Ankara kenti (Yurdugüzel, 2017: 41). 
Tunçer'in (2014) aktarımına göre Ankara, Orta Anadolu'nun kenarında, fakat İç Karadeniz Bölgesinin dağlık yörelerinden uzak olması ve korunmaya elverişli görünmesi İstanbul, Bursa, İzmir, Manisa, Kayseri, Konya, Karaman gibi önemli ticaret merkezleri ile bağlantılı olmasıyla kervan yollarının uğrağı olmuştur. Bölgede gerçekleşen ticaret kentin biçimlenmesini etkilemiştir. 16. Yüzyılda konut mahalleleri çarşılarının etrafında yerleşmeye başlamıştır. Ticaret ve zanaatla ilgili eylemler kale surlarının dışında, kaleyi kervan yollarına bağlayan yol üzerinde bir meydanda yoğunlaşmıştır. Bu dönemde ticaret Samanpazarı, Odunpazarı, Koyunpazarı, Atpazarı, Balıkpazarı gibi açık meydanlardaki pazarlarda gerçekleşen ticaret ve büyük hanlardaki depoluk ve toptan alım, satım işlerinden oluşmaktadır. Büyük yapılarda gerçekleşen ticaret eylemi şehrin biçimlenmesinde merkezi bir konuma bedesten yapısını koymuş, çevresinde de zanaatkârları toplamıştır (Tunçer, 2014).

Osmanlı kentinde yer alan ticari birimlerin yoğunluğu bir çarşı yaratmaktadır. Bu alan kentin ticari fonksiyonlarını barındırmasının yanı sıra aynı zamanda çeşitli sosyal fonksiyonları içermektedir. Öncelikle bu alanlarda belirli ticari faaliyetler bir arada yer almakta ve böylece aynı meslek grubundaki esnaflar grupları oluşmaktadır. Ayrıca kişisel hizmetleri sağlayacak konaklama, hamam ve berber gibi birimler kentli ve dışarıdan gelenlerin kişilerin ihtiyaçlarını karşılamaktadır. $\mathrm{Bu}$ sebeplerle bu alan, şehirde yaşayanların ve dışarıdan gelenlerin sosyal ve ekonomik açıdan buluşma yerini oluşturmaktadır (Şahinalp ve Günal, 2016). Mahmut Paşa Bedesteni'nin inşa edildiği dönemde (15.yy) söz edilen ticari faaliyetlerin yanı sıra Ankara'da kale dışında Hacı Bayram-1 Veli, Hızır İlyas Türbesi, Hacı Bayram-1 Veli, Mukaddem, Hacı Musa, Yeğenbey Hacı Arab, Direkli Cami, Ahi Tura, Balaban, İsfahani, Hacı Doğan, Hacı Seyid, Boyacı Ali, Gecik, Hemhüm, Rüstem Nail Mescidi, Karacabey, Tahtakale, Öğle Hamamı, Yeğenbey Medresesi de inşa edilmiştir (Yurdugüzel, 2017: 41).

Tablo 2: 19. Yüzyıl Başlarına Kadar Ulaşmış Vakıf Kökenli Başlıca Ankara Hanları ve

Kullanımları (Tunçer, 2014).

\begin{tabular}{l|l} 
Han adı & Kullanımı \\
\hline Bakır Hanı & Bakır Eşya Ticareti + İmalatı \\
\hline Kapan Hanı & Gida + Un Satışı \\
\hline Mahmut Paşa Bedesteni & Sof Ticareti + Kumaş Ve Değerli Eşya Alımı Satımı \\
\hline Kurşunlu Han & Ticari + Konaklama \\
\hline Suluhan & Konaklama \\
\hline Zağfirancı Hanı & Konaklama \\
\hline Çengel Han & Ham Deri + Tiftik + Yapağı + Yün \\
\hline Penbe Hanı & İplikçi + Bezci \\
\hline Yeni Han & $?$ \\
\hline Çukur Han & Konaklama \\
\hline Pilavoğlu Hanı & Konaklama \\
\hline Tuz Hanı & Ticaret \\
\hline Kıbrıslı Hanı & Tícaret \\
\hline Tahtakale Hanı & Demirciler + Kalaycılar \\
\hline Pirinç Hanı & Gida + Pirinç + Bakliyat \\
\hline
\end{tabular}

Mahmut Paşa Bedesteni, kentin kalbini oluşturan Ankara Kalesi'nin yanında konumlanmaktadır. Bu alan merkez nokta olmasinın yanı sira kentin ticari alanını da oluşturmaktadır. 16. ve 17. Yüzyıllarda eklenen Suluhan, Tuz Hanı, Un Kapanı Hanı, Safran Han, Yeni Han, Çukur Han, Çengel Han, Pilavoğlu Han, Pembe Hanı, Bakır Han, Kıbrıs Hanı ve Pirinç Han ve Esnaf Çarşıları Bölgenin ticari işlevini kuvvetlendirmektedir. Bu birimlerin yanı sıra merkezde bulunan cami yakınlarında kitapçılar, ciltçiler ve terlikçiler ve deri eşya satıcıları yer alırken dokumacılık, marangozluk, çilingirlik ve bakırcılık kentin diğer yaygın iş kolları bulunmaktadır (Yurdugüzel, 2017: 43, 52,53). Bu yapılar bedesten etrafinda yer alan birimlerin kent içindeki ticari değerini ve merkezi önemini göstermektedir. Konaklama fonksiyonu içeren hanlar, 
bedestene şehir dışından gelen kişilerin geceleme ihtiyaçlarını karşılamasıyla bedesten fonksiyonunu destekleyen bir birim olarak izlenmektedir (Bkz. Tablo 1). Kent çarşısında yer alan birimlerin birbiri ile kurduğu mekânsal komşuluğun bedestenin güvenilirliğini arttırman unsurlardan olduğu söylenebilmektedir. Bütün bunlar düşünüldüğünde kale çevresinde yer alan birimlerin bir bütün oluşturduğu, bedestenin de bu bütünün ayrılmaz bir parçası olarak Cezar'ın (1985) belirttiği gibi sosyal ve idari görevleri içerdiği düşünülmektedir.

\section{Ankara Mahmut Paşa Bedesteni'nin (Anadolu Medeniyetleri Müzesi) 21.yy'da bulunduğu kent çevresi ile ilişsisi}

Cumhuriyetin ilanından sonra yeni devletin başkenti olarak belirlenen Ankara, planlama çalışmaları için deneysel bir alan oluşturmuş; sırasıyla Lörcher Planı, Herman Jansen, 1990 Nizamnamesi gibi çalışmalarla kent geliştirilmiştir. Kent içindeki gelişim günümüzde ulus olarak anılan Ankara Mahmut Paşa Bedesteni'nin bulunduğu bu alanla kısıtlı kalmayıp kent zamanla genişlemeye ve yeni merkezler yaratmaya devam etmiştir (Bkz. Şekil 6 ve 7). Büyüyen kent Altındağ, Çankaya, Yenimahalle, Keçiören, Mamak, Sincan, Gölbaşı, Etimesgut, Çubuk, Akyurt, Kalecik, Kazan, Ayaş, Pursaklar, Bala, Elmadağ, Evren, Şereflikoçhisar, Haymana, Güdül, Nallıhan, Beypazarı, Polatlı, Çamlıdere ve Kızılcahamam olmak üzere 25 ilçeye ayrılmıştır (URL-1).

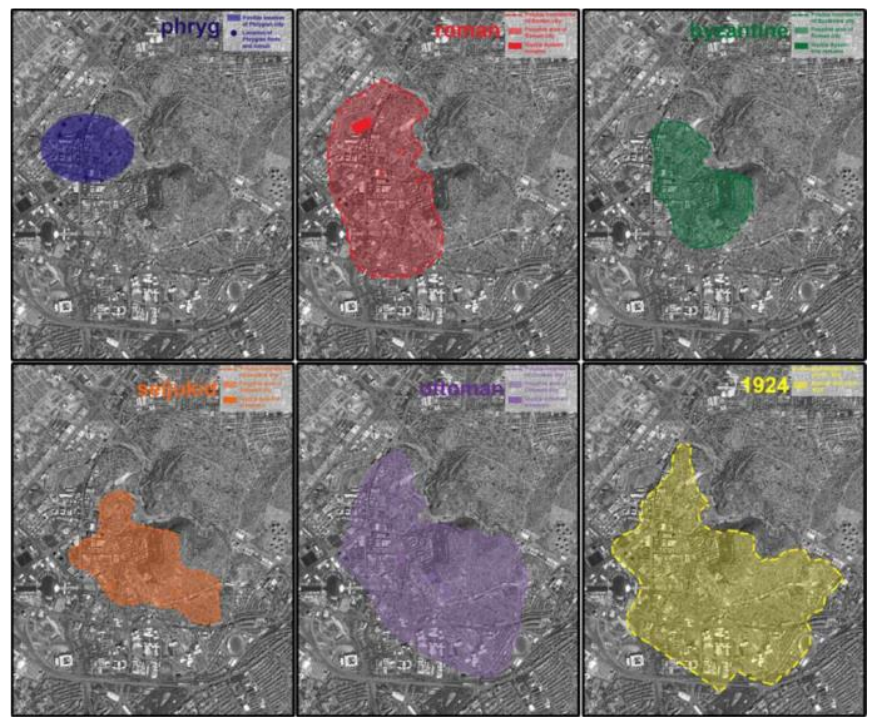

Şekil 6: Kentin gelişim şeması (Yurdugüzel, 2017: 63)

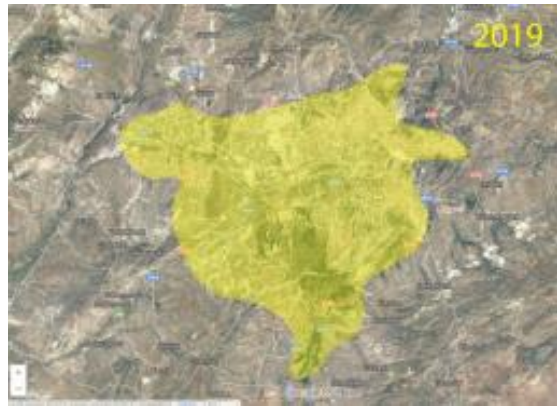

Şekil 7: Ankara'nın 2019 yılındaki gelişimi

Kentin ilçeleri her biri aynı zamanda alt merkezlere ayrılmakta, her semtin kendi içinde ticari bir merkezi bulunmaktadır. Her ilçede günümüzdeki kamusal faaliyetler, insan etkileşimleri, teknolojik koşullar, alışveriş pratikleri dolayısıyla yeni mekânsal biçimlenmeleri ve yeni yapı türleri oluşmuştur. Geçmişte ticari eylemlerin gerçekleştiği çalışmanın konusunu oluşturan bedesten ve han, 
pazarlar yerini alışveriş merkezlerine, konaklama içi kullanılan hanlar yerlerini otellere, imalat yapılan hanlar ise yerlerini sanayi bölgelerindeki tesislere bırakmıştır. Kendileri ise ya yangında harap olmuş, terk edilmiş ya da restore edilip yeniden işlevlendirilen mekânlar olarak kentte var olmaya devam etmiştir.

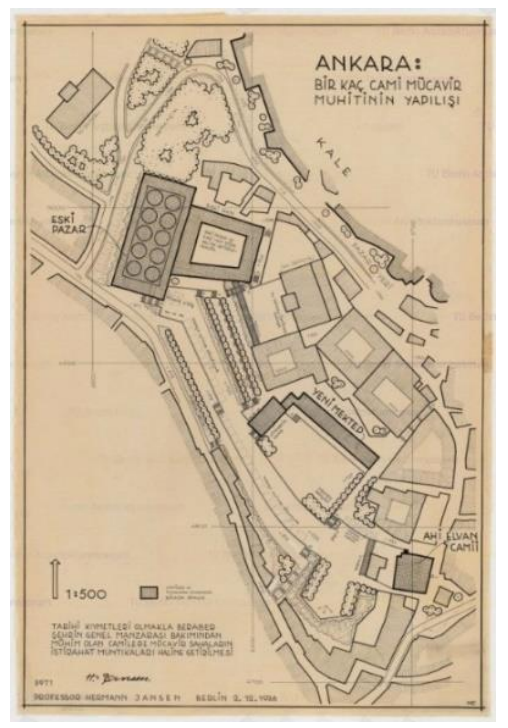

Şekil 8: Jansen'in Mahmut Paşa Bedesteni ve Hanlar bölgesi düzenlemesi (Tunçer, 2014)

Çalışmada ele alınan Mahmut Paşa Bedesteni'nin bulunduğu bölge, kentinin gelişmesini büyük ölçüde etkileyen Jansen planı ile Hacıbayram Camii ve çevresini, Bent deresini, Kaleyi, Hanlar bölgesini, Samanpazarı, Atpazarı, Koyunpazarı içine alan bölge, eski Ankara olarak tanımlanmıştır (Tunçer, 2005; Asar, 2012). Kent içinde korunması gereken bir alan olarak belirtilmiştir. Jansen planına göre Ulus bölgesinde Karaoğlan Çarşısı, Tahtakale Çarşısı, Anafartalar, Çıkrıkçılar yokuşu, Atpazarı, Samanpazarı, Koyunpazarı, Bankalar Caddesi ve Çankırıkapı Caddesi Ulus Merkezi'nin çekirdeğini oluşturmaktadır (Tunçer, 2014). Tarihi kent merkezini oluşturan Roma Hamamı, Ankara Kalesi ve Hamamönü Mahallesi, İsmetpaşa, Atıfbey-Hıdırlıktepe alanlarını kapsayan bölgede ise 2007 tarihli Ankara Tarihi Kent Merkezi Yenileme Alanı 1/5000 ve1/1000 Ölçekli Koruma Amaçlı İmar Planları ile tarihi kent merkezindeki işlevsizleşme ve çöküntü alanına dönüşümün engellenmesi amacıyla bölgenin ticari, turistik ve kültürel gelişimine uygun olarak restore ve edilmesi hedeflenmiştir (Tunçer, 2013).

Tablo 3: 21.Yy'da Hanların Kullanımı

\begin{tabular}{l|l} 
Han adı & Kullanımı \\
\hline Bakır Hanı & Günümüze ulaşamamıştır. \\
\hline Kapan Hanı & Günümüze ulaşamamışır. \\
\hline Mahmut Paşa Bedesteni & Anadolu Medeniyetler Müzesi \\
\hline Kurşunlu Han & Anadolu Medeniyetler Müzesi \\
\hline Suluhan & Ticaret (Zücaciye, nalburiye, billuriye, baharatçı vb.) \\
\hline Zağfirancı Hanı & Rahmi Koç Müzesi \\
\hline Çengel Han & Rahmi Koç Müzesi \\
\hline Penbe Hanı & Günümüze ulaşamamıştır. \\
\hline Yeni Han & Günümüze ulaşamamıştır. \\
\hline Çukur Han & Konaklama \\
\hline Pilavoğlu Hanı & Gastronomi, turistik ticaret \\
\hline Tuz Hanı & Günümüze ulaşamamışıtır. \\
\hline Kıbrıslı Hanı & Günümüze ulaşamamıştır. \\
\hline Tahtakale Hanı & Günümüze ulaşamamıştır. \\
\hline Pirinç Hanı & Gastronomi, turistik ticaret \\
\hline
\end{tabular}




\section{Ankara Mahmut Paşa Bedesteni’nin Anadolu Medeniyetler Müzesi’ne dönüşümüi}

1982 yılında başlatılan çalışmalarda Hacıbayram Çevresi, Suluhan Çevresi, Çıkrıkçılar Yokuşu Çevresi, Anadolu Medeniyetleri Müzesi Çevresi, Karyağdı Türbesi Çevresi, HasırcılarOsmanlı Kavşağı Bağlantısı ve Eski Hamam Çevresi, Bend Deresi Dolmuş Durakları Çevresi, Akköprü Çevresi uygulama alınan öncelikli alanlar olmuştur (Tunçer, 1998). Böylece çalışmanın kapsamına giren Mahmut Paşa Bedesteni, Ankara Kalesi, Çengel Han, Çukur Han, Zağfiran (Safran) Han, Suluhan, Aslanhane (Ahi Şerafeddin) Camii, Alaaddin Camii gibi yapilar ise restorasyon uygulamaları ile hayata yeniden kazandırılmıştır. Bedesten çevresi daha çok turistik bir bölgeye dönüştürülmüsstür. Yapının komşuluklarında, Kale’ye doğru çıkan yollarda toptan ve perakende ticaretin görüldüğü, geleneksel zanaatların bulunduğu görülmektedir (Yurdugüzel, 2017: 101). Hanların çoğunluğu günümüze ulaşamamakla birlikte, daha önce ticari kullanımlarda bulunulan bazı hanların ise artık gastronomik ya da günlük atölyeleri içeren kültürel etkinlikler için kullanıldığı yer yer de antika eserlerin, hediyelik eşyaların satıldığı turistik ticaretin gerçekleştiği yerlere evrilmiştir (Bkz. Tablo 2).

Eski eserlere verilen önem topraklarımızda, XIX. yüzyıl ortalarından itibaren görülmektedir. Avrupa'da doğan modernite projesi, 1840'lı yıllardan itibaren Osmanlıları da etkilemiştir (Tekeli, 1998; Kejanlı ve diğerleri 2007). Bu bağlamda Osmanlı Devleti Asar-1 Atika Nizamnameleri, "Muhafaza-i Asar-1 Atika Encümeni", Ebniye Nizamnamesi oluşturulmuştur (Kejanlı ve diğerleri 2007). Kurtuluş Savaşı'nın ardından Gazi Mustafa Kemal'in buyruğu ile Maarif Vekili İsmail Safa tarafindan 'Müzeler ve Asar-1 Atika Hakkında Talimat' ile bir genelge oluşturulmuştur (Madran, 1996). Kültür varlıklarını koruma gayreti ile kültürel mirasın korunması, teșhir edilmesi ve eski eserlerin restorasyonlarına verilen önem artmıştır (Çetin, 2007). Osmanlı İmparatorluğu'ndan kalan 'Müze-i Hümayun', 'Ebniye-i Emiriye (Kamu Yapıları) ve Vakfiye İnşaat ve Tamiratı Hakkında Nizamname', 'Evkaf Hümayun Nezareti', 'İnşaat ve Tamirat Müdüriyet-i Umumiyesi' (Öztürk, 1995,193; Madran, 1996). Cumhuriyet tarihinin koruma ve müzecilik alanının ana çizgilerini belirlemiştir (Madran, 1996). Bakanlıklar arasında, 'Şeri'ye ve Evkaf Vekaleti' ile 'Maarif Vekaleti'ne yer verilmiş, korumayla ilgili iki ana kurum Cumhuriyet döneminde varlığını devam ettirmiştir. Ebniye-i Emirİye ve Vakfiye İnşaat ve Tamirat Hakkında Nizamnamesi yapılan değişikliklerin ardından 1936 tarihine kadar kullanılmıştır (Madran, 1996).

1930'lu yıllardan itibaren kent yönetimi ve kent planlaması da korumaya ağırlık verecek şekilde gelişmiştir. 1932'de onaylanan H. Jansen'in Ankara imar planı bu yaklaşıma örnek olmuştur (Kejanlı ve diğerleri 2007). 1935 yılında Atatürk, koruma hareketlerine bir kez daha ivme kazandırmış ve yeni gelişmekte olan ulusal arkeolojik etkinliklerin yönlendirilmesine ilişkin ilkeler belirlemiştir. Türk Tarih Kurumu Başkanı Hasan Cemil Çambel ve Asbaşkanı Afet İnan tarafından metne dökülen ilkelerden "Memleket içinde ve dağınık bir halde açıkta duran tarihi eserleri, tahrip olunmak, çalınmak, satılmak, 'ziya'a uğramak' ve zamanla kendi kendine tahrip olmak tehlikelerinden korumak için hükümetçe bütün tedbirleri almak" (Madran, 1996) doğrudan korumay1 ilgilendiren bir maddedir.

Atatürk çıktığı gezide, Konya'daki Selçuklu anıtlarını gezmiş, eserlerin onarılması gerekliliğini "Acele ve Önemlidir" kaydı İsmet İnönü’ye bildirmiştir. Böylece memleketin her yerinde eski eserlerin onarımı için bir çalışma başlamıştır (Yücel, 1999: 70-71; Çetin, 2007). Osmanlı'dan kalan ve feshedilen kurumların ülkenin yeni kimliğini yansıtacak şekilde dönüştürülmesi amaçlanmıştır. Bu doğrultuda Atatürk'ün direktifiyle üyeleri Macit Kural, Viyana Arkeoloji Enstitüsü’nden Prof. Miltner, Sedat Çetintaş, İstanbul Müzeleri tescil uzmanı Selahattin Kandemir ve fotoğraf uzmanı Schüller olan Anıtları Koruma Komisyonu kurulmuştur (Coşkun ve Binan, 2013). Bu süreçte ilk olarak Ayasofya onarılmış, ardından İstanbul Sultanahmet ve Beylerbeyi Camileri, Edirne Selimiye ve Üçşerefeli Camileri, Elmalı Ömer Paşa Camisi, Manisa Muradiye Camisi ve Konya Mevlana Türbesi ele alınmıştır (Öztürk, 1995, 202; Madran, 1996). 
Afyon-Gedik Ahmet Paşa Medresesi, Tokat-Ali Tusi Türbesi, Kayseri- Ali Cafer, Sırçalı ve Hunat Hatun Künbetleri, Selçuk-İsabey Camisi, Denizli-Akhan Kervansaray, Erzurum-Çifte Minareli Medrese, Söğüt-Ertuğrul Türbesi yapıları bu kapsamda onarılmıştır. Bu yapılar arasında Ankara Mahmut Paşa Bedesteni ve İstanbul Topkapı Sarayı'na ağırlıkla yoğunlaşılmıştır (Madran, 1996). $\mathrm{Bu}$ eserlerin yanı sıra korunması gereken 3500 eser uzmanlar tarafindan saptanmıştır (Tekeli, 1998; Kejanlı ve diğerleri 2007). Bu bağlamda, eski yapıların yeniden kullanılma fikri paralelinde diğer bedestenlerin dönüşümü Tarsus Kırkkaşı, Sandal, Zincirli, Kayseri, Gaziantep Bedestenleri turistik ticareti; Vezirköprü, Yusuf Paşa, Uşak, Tekirdağ, Afyonkarahisar, Kastamonu, Bursa ve Kütahya Bedestenleri ticareti; Tire, Niğde, Manisa Rum Mehmet Paşa ve Mahmut Paşa Bedestenleri ise kültürel faaliyetleri kapsayacak şekilde geliştirilmiştir (Bkz. Tablo 3 ve 4).

Tablo 4: Kültürel Faaliyetleri İçerecek Şekilde Dönüşen Bedestenler

Kültürel faaliyetleri içerecek şekilde dönüşen bedestenler

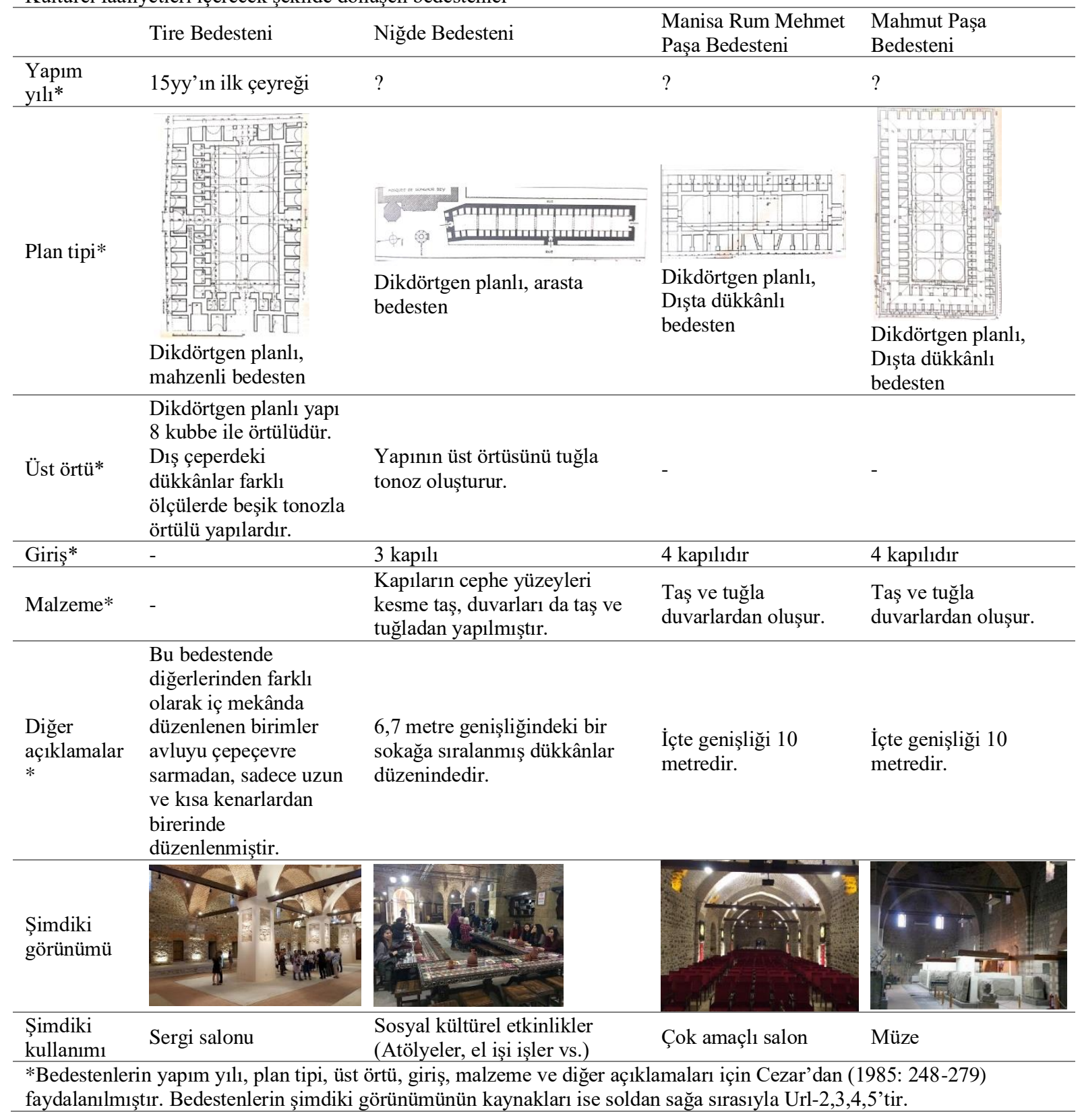


Tablo 5: Dönüşüm Geçiren Diğer Bedestenler

\begin{tabular}{|c|c|c|c|c|}
\hline Dönüşüm ge & diğer bed & stenler & 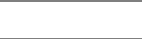 & \\
\hline & $\begin{array}{l}\text { Yapim } \\
\text { y1l1 }\end{array}$ & Plan tipi & $\begin{array}{l}\text { Şimdiki } \\
\text { kullanımı }\end{array}$ & Şimdiki görünümü \\
\hline $\begin{array}{l}\text { Kırkkaşık } \\
\text { Bedesteni }\end{array}$ & 1579 & $\begin{array}{l}\text { Dikdörtgen } \\
\text { planlı, } \\
\text { mahzenli } \\
\text { bedesten }\end{array}$ & $\begin{array}{l}\text { Turistik } \\
\text { ticaret }\end{array}$ & \\
\hline $\begin{array}{l}\text { Sandal } \\
\text { Bedesteni* }\end{array}$ & $?$ & $\begin{array}{l}\text { Dikdörtgen } \\
\text { planlı, } \\
\text { mahzenli } \\
\text { bedesten }\end{array}$ & $\begin{array}{l}\text { Turistik } \\
\text { ticaret }\end{array}$ & \\
\hline $\begin{array}{l}\text { Zincirli } \\
\text { Bedesteni }\end{array}$ & $\begin{array}{l}\text { XVIII. } \\
\text { yüzyılın } \\
\text { ilk } \\
\text { çeyreği }\end{array}$ & $\begin{array}{l}\text { Dikdörtgen } \\
\text { planlı, } \\
\text { mahzenli } \\
\text { bedesten }\end{array}$ & $\begin{array}{l}\text { Turistik } \\
\text { ticaret }\end{array}$ & \\
\hline $\begin{array}{l}\text { Kayseri } \\
\text { Bedesteni* }\end{array}$ & $?$ & $\begin{array}{l}\text { Dikdörtgen } \\
\text { planlı, } \\
\text { arasta } \\
\text { bedesten }\end{array}$ & $\begin{array}{l}\text { Turistik } \\
\text { ticaret }\end{array}$ & \\
\hline $\begin{array}{l}\text { Vezirköprü } \\
\text { Bedesteni* }\end{array}$ & $?$ & $\begin{array}{l}\text { Kare planlı } \\
\text { arastalı } \\
\text { bedesten }\end{array}$ & Ticaret & \\
\hline $\begin{array}{l}\text { Yusuf Paşa } \\
\text { Bedesteni }\end{array}$ & $?$ & $\begin{array}{l}\text { Dikdörtgen } \\
\text { planlı, } \\
\text { mahzenli } \\
\text { bedesten }\end{array}$ & Ticaret & \\
\hline $\begin{array}{l}\text { Uşak } \\
\text { Bedesteni }\end{array}$ & 1901 & $\begin{array}{l}\text { Dikdörtgen } \\
\text { planlı, } \\
\text { mahzenli } \\
\text { bedesten }\end{array}$ & Ticaret & \\
\hline $\begin{array}{l}\text { Tekirdağ } \\
\text { Bedesteni* }\end{array}$ & $?$ & $\begin{array}{l}\text { Dikdörtgen } \\
\text { planlı, } \\
\text { arasta } \\
\text { bedesten }\end{array}$ & Ticaret & \\
\hline
\end{tabular}

www.turkishstudies.net/social 


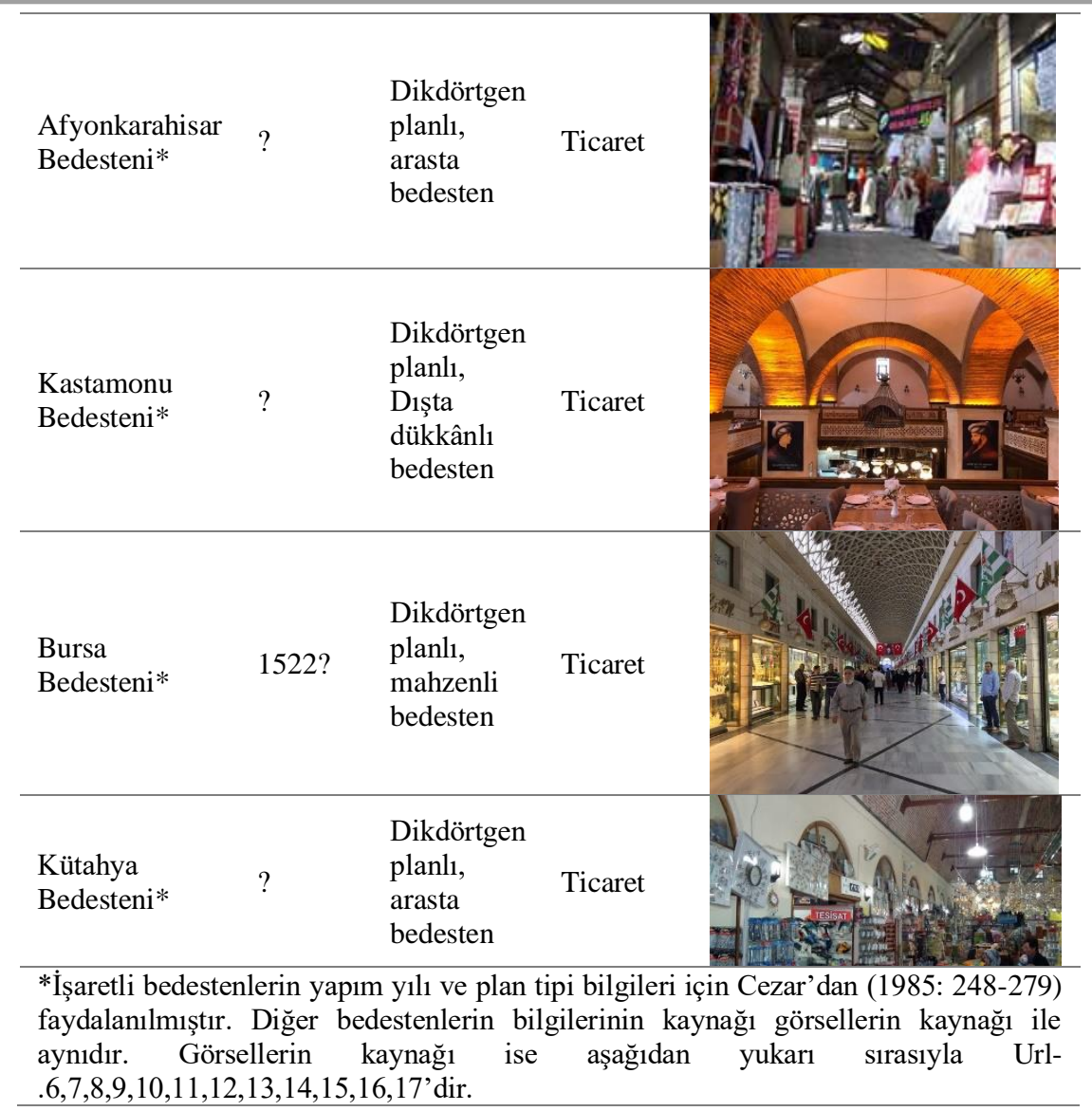

Madran'ın aktarımına göre 1920'de Maarif Vekaleti'ne bağlı olarak, müzecilik hizmetleri için 'Türk Asar-1 Atikası Müdürlüğü' kurulmuştur (Önder, 1989, 1837). Bu birim daha sonra 'Hars (Kültür) Müdürlügü̈' adını almıştır (Ozankaya, 1994, 352). Hars idaresi müzecilik ve kazı hizmetlerinden sorumlu olmuş, 922'de Asar-1 Atika ve Müzeler, Kütüphaneler ve Güzel Sanatlar Müdürlüklerine ayrılmasıyla koruma görevleri arasında yer almıştır (Madran, 1996). Yurdun çeşitli yerlerde yapılan kazılarla elde edilen eserlerin sergilenme ve korunma gerekliliği düşünülünce ise Hitit Müzesi kurma fikri doğmuştur. Bu doğrultuda Mahmut Paşa Bedesteni, bu eserlerin sergileneceği bir alan olarak seçilmiş, 1937 y1lında o dönemde koruma kurulu üyesi olan mimar Macit Kural ve inşaatçı Zühtü Başar Nazi zülmünden kaçan kent plancısı Jansen, Unger, Egli gibi Avrupalı profesörlerden, Landsberger, Von der Osten, Rohde, Guterbock gibi isimlerle yapının Anadolu Medeniyetleri Müzesi olarak uyarlanma çalışmalarına başlanmıştır (Kurtay ve diğerleri, 2003). 1938 yılında başlayan dönüşüm 1968 yılında tamamlanmıştır. Bu tarihten itibaren bedesten, Anadolu Medeniyetleri Müzesi olarak işlemektedir. 1997 yılında ise Anadolu Medeniyetleri Müzesi Avrupa'da yılın müzesi seçilmiştir.

Mahmut Paşa Bedesteni Alman mimar Bruno Taut'un harabe estetiklerine dokunulmadan en az müdahale ile onarılarak Hitit eserlerini sergileyecek bir müze olarak kullanılmasını önermesiyle, bedestenin üst örtüsü özgün malzemeyle onarılarak sergi salonuna dönüştürülmüsstür. Yapının yanında yer alan Kurşunlu Han'ın ise, müzenin depo işlevini yerine getirmek üzere komplekse katıldığ 1 görülmektedir (Coşkun ve Binan, 2013). Müzenin depo kısmını oluşturan Kurşunlu Han ziyaretçi kullanımına kapalı bir işleve sahip iken sergi salonunu oluşturan bedesten aynı zamanda kendisini de bir seyir nesnesi olarak ortaya koymaktadır. Bedestenin taş duvarları arkeolojik kalıntılar, kilden eserler, heykeller ve ziynet eşyalarının sergilenmesinde bir altlık olarak 
kullanılmaktadır. Bedesteninin kubbeli iç mekânı ise taş eserlerin sergilendiği, aynı zamanda çok amaçlı salon olarak kullanılan bir hacim sunmaktadır (Bkz. Şekil 11 ve 12). Bedestenin çeperine ise dört yönden eklemlenen yeni bir strüktür eklenerek sergi mekânı genişletilmiştir (Bkz. Şekil 13). Şekil 9'de eklenen kısım farklı üst örtüsüyle anlaşılmaktadır. Bu bölümde taş, kil, çeşitli metallerden eserler sergilenmektedir.

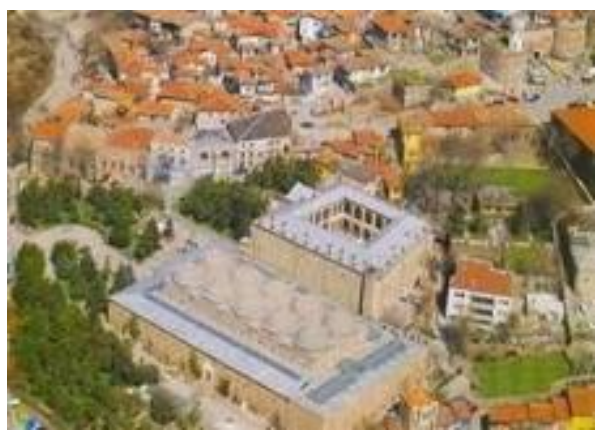

Şekil 9: Anadolu Medeniyetleri Müzesi (Tunçer, 2014)
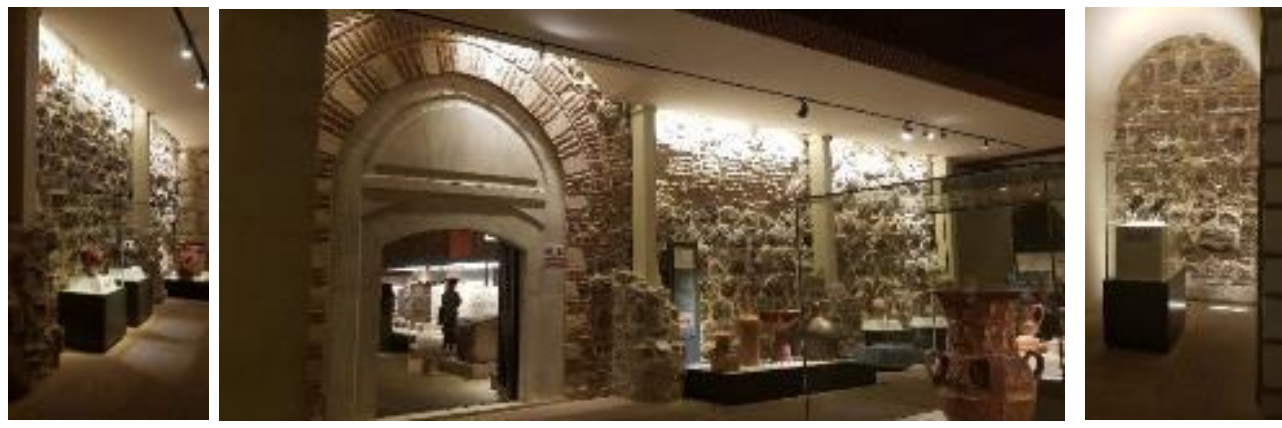

Şekil 10: Bedestenin taş duvarlarının sergi elemanı olarak kullanımı
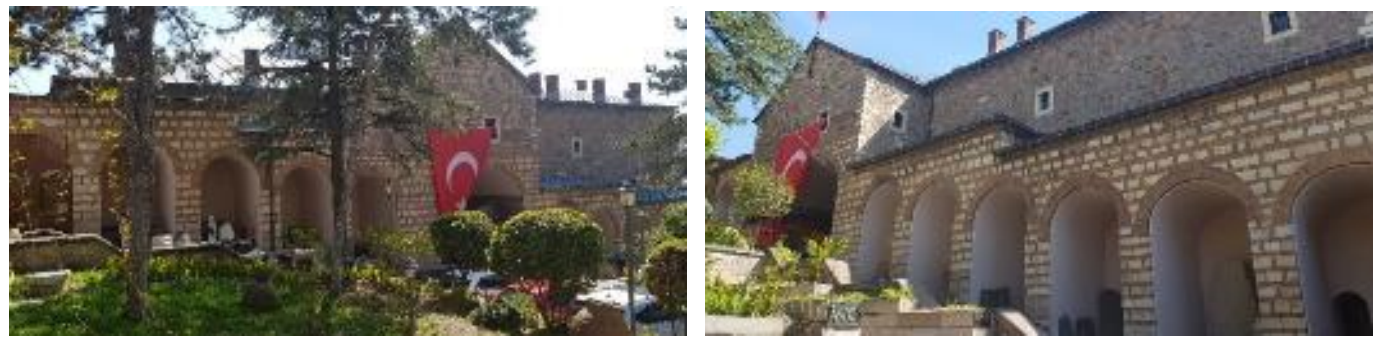

Şekil 11: Kurşunlu Han'1n müze deposu olarak kullanımı

Müze yapısı Ankara'nın önemli ve büyük müzelerinden biridir. Aynı zamanda turistik bölgede konumlanması ziyaretçi çeken bir sosyal tutkal olarak çalışmasını sağlamaktadır. Müze her yaştan kullanıcının ziyaretine açıktır. Müze-kafe, dinlenme alanları, hediyelik eşya birimi ve açık alan düzenlemeleri de kullanıcıların ilgilini çeken yan kullanımlar olarak mekânda yer almaktadır. Farklı kotlarda düzenlenen iç mekân ve açık alan kütleye hareket katmakta ve bu yan fonksiyonlara alan açmaktadır. Açık alan düzenlemesi de içe dönük bir yapı türü olan bedesteni kamusal açık alan ile ilişkilendirmiş alanda yeni bir kamusal yaşam yaratmıştır (Bkz. Şekil 14). Böylelikle bedesten kentte daha önce bulunmayan bir yapı türünde, yeni bağlamına uyum sağlamış bir şekilde kentliler tarafından benimsenen bir kullanımı içermektedir. Uygulama ile bedesten kentin yeni dinamiklerine göre dönüşmüştür. 

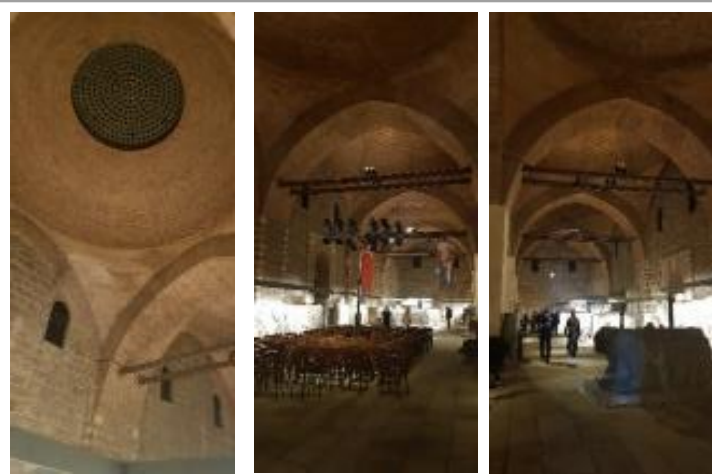

Şekil 12: Bedestenin kullanımı
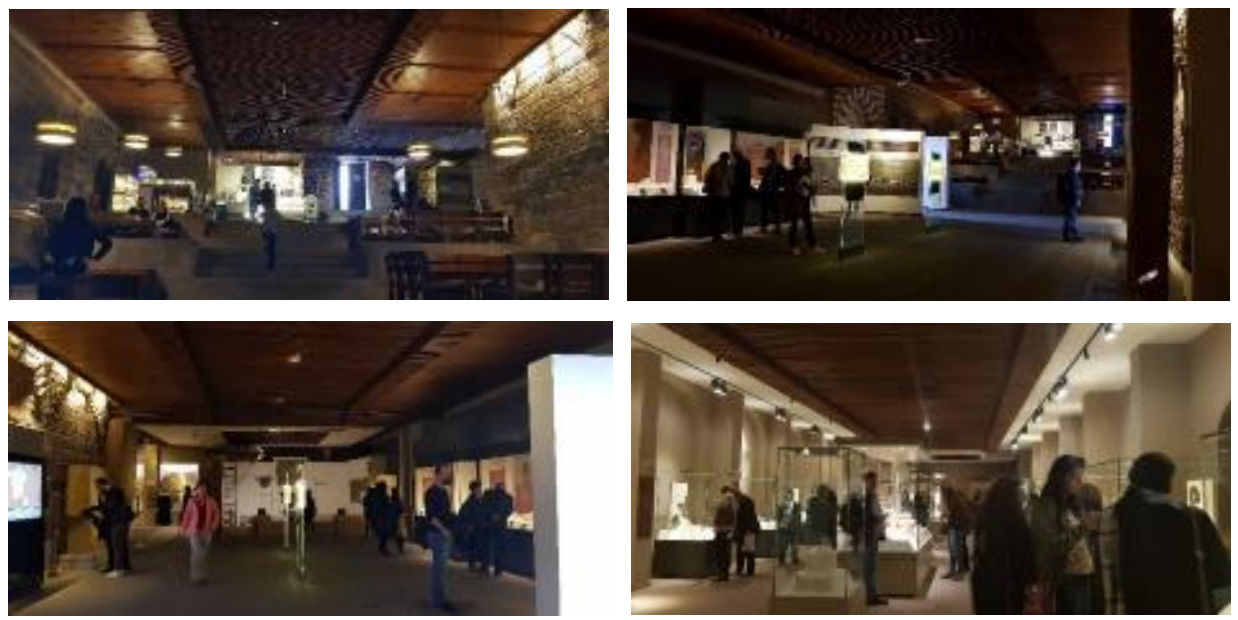

Şekil 13: Bedestene ek yapılan iç mekânın kullanımları
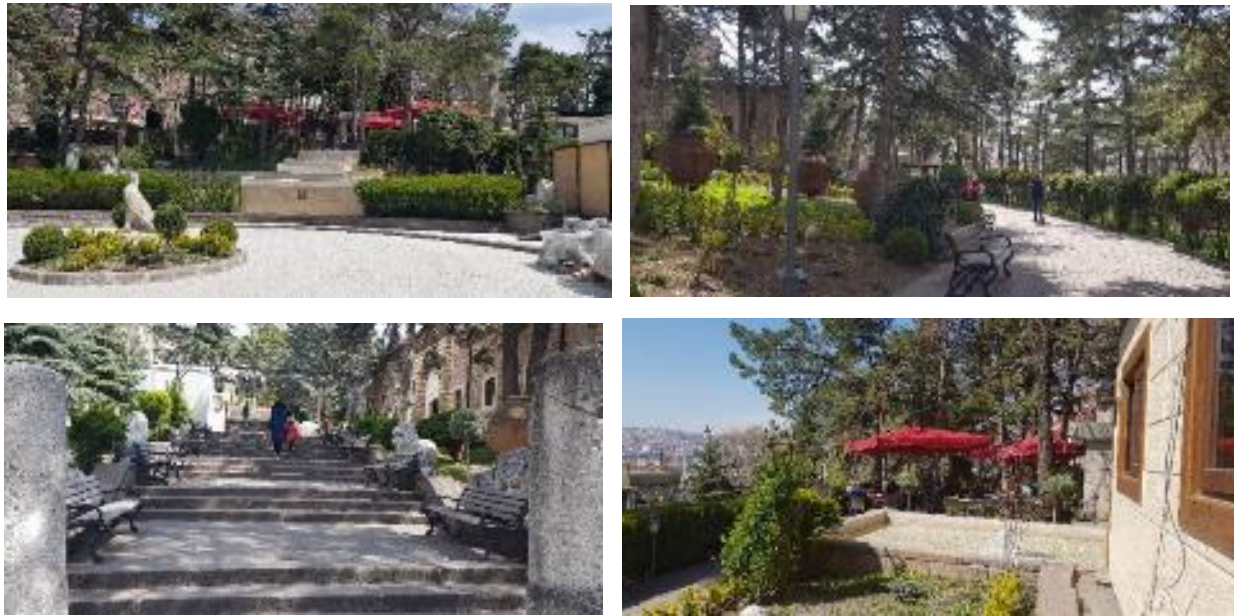

Şekil 14: Müze dış mekân düzenlemeleri

\section{Sonuç}

Osmanlı döneminde kentin merkezi genellikle ticaret eylemelerinin gerçekleştiği canlı, hareketli alanlardan oluştuğu anlaşılmaktadır. Bu alanlarda yer alan birimlerin ise kentsel, ekonomik, sosyal, ticari gibi birçok farklı yönden nitelikleri bulunmaktadır. Kentin merkezinde yer alan mimari elemanlardan biri bedestenlerdir. Bu yapı kentin diğer ticaret yapıları ve konaklama, ibadet gibi yan birimlerle ilişki kuracak biçimde kurgulanmaktadır. Döneminde yarı-resmi ticaret mekânı olarak 
hem idari hem de ekonomik hayatta varlık gösteren bir düğüm noktası gibi çalışmıştır. Kullanıcılarını ise, toptan ticareti ve günümüzün bankacılık faaliyetleri gibi kullanımlarını barındırması sebebiyle toplumun üst-zengin kesimi oluşturmuştur.

Günümüzde devletin rejim değiştirmesine müteakip birçok kent planlama çalışmaları gerçekleştirilmiş; kentin gelişmesi sağlanmıştır. Çok merkezli ve yine odağında ticari birimlerin yer aldığ 1 parçalardan metropoller oluşmuştur. Kent içinde yer alan eski yapılar ise çoğunlukla bakımsızlıktan ya da yangından günümüze erişememiştir. Halen varlığını devam ettiren bedestenlerden bazıları ise yeni fonksiyonlar kazanarak değişen ihtiyaç ve beklentiler ile işlev değiştirmiştir. Yeni kullanımı kentli tarafindan benimsenen, kentin yeni dinamiklerine uyum sağlayanlar canlılığını korumaya devam etmiştir.

$\mathrm{Bu}$ çalışmada Osmanlı kentinin önemli bedestenlerinden biri olan Mahmutpaşa Bedesteni'nin Anadolu Medeniyetler Müzesi'ne dönüşümü ele alınmıştır. Kentin zaman içindeki dönüşümü doğrultusunda bedestene, önceki kullanımında yer almayan, müze işlevi ithaf edilmiştir. $\mathrm{Bu}$ dönüşüm sayılan nedenlerden ötürü başarılı bir yeniden işlevlendirme uygulaması olarak görülmektedir. Bedesten bu dönüşüm ile yalnızca toplumun bir kesimine (toptan ticaret yapanlar, kasa kullanımı ihtiyacı duyanlar gibi toplumun orta-üst kesimine) hitap ederken herkese açık bir yere dönüşmüş, çevresinde tasarlanan açık alanları ile kamusal açık kullanımını içine katmış, açık alanı değişen kamusal kullanımlara (Örn. gastronomik faaliyetler, her yaştan kullanıcının dinlenme ihtiyacı için oturma alanları, gruplar için buluşma eylemleri vb.) imkân sağlayacak şekilde düzenlenmiştir. Ayrıca yapının bulunduğu bölge daha önceleri ticari birimlerin yoğunlaştığı bir bölgedeyken, günümüzde alanın artık turistlik faaliyetlere mekân sağlamaktadır. Sonradan tanımlanan turistik bir rotada bulunması müzeye dönüştürülen yapının canlı bir mekân olarak kullanımında teşvik edici görülmektedir. Buna karşın kültürel faaliyet içerecek şekilde dönüşen bedestenlerin içinde en yoğun kullanıcı yüküne sahip bedestenin Anadolu Medeniyetleri Müzesi (Mahmut Paşa Bedesteni) olduğu göz önüne alındığında, yapının bunca yükü strüktürel olarak ne kadar süre kaldırıp kaldıramayacağı düşünülmelidir. Ayrıca yapıya eklenen farklı mekânların bedestenin üzerindeki kalıcı ve geçici etkilerinin incelenmesi gereklidir. Böylece yapıda gelişecek geri dönüştürülemez tahribatların önüne geçilecektir.

Değişen kent kullanımları ve mekânsal biçimlenmeler doğrultusunda dönüşüm kaçınılmazdır. Bu noktadan hareketle tarihsel bilincinin gelişimi ile kentte bulunan diğer eski eserlere sahip çıkılmalı, kentin değișen kullanımları doğrultusunda strüktürel durumu kritik edilerek hayata kazandırılmalıdır. Bununla birlikte mevcut ve projelendirme aşamasındaki yapıların da bir gün eski eser olarak görülüp işlev dönüştürme ihtimali olduğundan, esnek planlama ile kurgulanmas1 önemlidir.

\section{Kaynakça}

Aliağaoğlu, A., \& Uğur, A. (2016). Osmanlı Şehri. Süleyman Demirel Üniversitesi Fen-Edebiyat Fakültesi Sosyal Bilimler Dergisi, 38: 203-226.

Asar, B. (2012). Ankara Ulus Tarihi Kent Merkezindeki Ticaret Binalarının Değissimi Ve Mekânsal Analizi (Doctoral dissertation, Selçuk Üniversitesi Fen Bilimleri Enstitüsü).

Aslanapa, O. (1986). Osmanlı Devri Mimarisi, İstanbul: İnkılap Yayınevi.

Atalan, Ö. (2016). 15. ve 16. Yüzyıllarda Yapılmış Osmanlı Han Yapılarının Mekânsal Analizi.

Cantay, T. (1988a). Fetihten Sonra Mimar Sinan'a Kadar Osmanlı Sanatı (Mimarbaşı Koca Sinan Yaşadığı Çağ Ve Eserleri 1, içinde). İstanbul: T.C. Başbakanlık Vakıflar Genel Müdürlüğü. 
Cantay, T. (1988b). Osmanlı Devleti'nin Kuruluşundan İstanbul'un Fethinin Sonuna Kadar Osmanlı Sanatı (Mimarbaşı Koca Sinan Yaşadığı Çağ Ve Eserleri 1, içinde). İstanbul: T.C. Başbakanlık Vakıflar Genel Müdürlüğü.

Cerasi, M. M. (1999). Osmanl Kenti Osmanl İmparatorluğu'nda 18. ve 19. Yüzylllarda Kent Uygarlığ ve Mimarisi (Çev. Aslı Ataöv), İstanbul: Yapı Kredi.

Çetin, Y. (2007). Mustafa Kemal Atatürk Döneminde (1920-1938) Müze Ve Eski Eserler Konusunda Yapılan Çalışmalar. Sanat Dergisi, 12: 117-121.

Cezar, M. (1985). Tipik Yapılarıyla Osmanlı Şehirciliğinde Çarşı Ve Klasik Dönem İmar Sistemi. İstanbul: Mimar Sinan Üniversitesi.

Coşkun, B. S., \& Binan, D. (2013). Erken Cumhuriyet Döneminde Anıtsal Yapıların Güçlendirilmesi Yaklaşımları. TMMOB İnşaat Mühendisleri Odası İstanbul Şubesi.

Goodwin, G. (2012). Osmanlı Mimarlı̆̆ı Tarihi, çev. Müfit Günay (ilk basım tarihi 1987), İstanbul: Kabalc1 Yayınları.

Iş1klar, S. (2017). Vitality of The Cities. International Journal of Architectural Engineering Technology, 4: 18-23.

Kejanlı, D. T., Akın, C.T., Yılmaz, A. (2007). Türkiye'de Koruma Yasalarının Tarihsel Gelişimi Üzerine Bir İnceleme. Elektronik Sosyal Bilimler Dergisi, 6(19): 179-196.

Kurtay, C., Aybar, U., Başkaya, A., \& Aksulu, I. (2003). Müzelerde Algılama Ve Aydınlatma Kriterlerinin Analizi: Ankara-Anadolu Medeniyetleri Müzesi Orta Holü. Gazi Üniversitesi Mühendislik-Mimarlık Fakültesi Dergisi, 18(2).

Madran, E. (1996). Cumhuriyetin İlk Otuz Yılında (1920-1950) Koruma Alanının Örgütlenmesi. Metu Journal Of Faculty Of Architecture, 16(1-2), s. 59-97.

Özdes, G. (1998). Türk Çarşıları, Ankara: Tepe Yayınları.

Şahinalp, M. S., \& Günal, V. (2016). Osmanlı Dönemi Anadolu Şehirleri Çarşı Sisteminin Fonksiyonel Analizi. Electronic Turkish Studies, 11(8).

Tunçer, M. (1998). Kentsel Tasarımın Tarihsel Çevre Korunmasında Etkin Olarak Kullanımı," Böl ve Yönet Modeli": Ankara, Konya, Antalya Tarihi Kent Merkezleri. Kentsel Tasarım ve Uygulamalar Sempozyumu, Farklı Ölçeklerde Kentsel Tasarım, MS Ü. Mimarlık Fakültesi Şehir ve Bölge Planlama Bölümü.

Tunçer, M. (2013). Ankara Tarihi Kent Merkezi Yenileme Alanı Koruma Planı, Niteliği Ve İptaline İlişkin Gerekçeler. Ankara araştırmaları dergisi, 1(2): 10-34.

Tunçer, M. (2014). Ankara'da Vakıf Mülkiyetindeki Bedesten ve Hanların Gelişimi ve Şehir Ekonomisinin Dönüsüm Süreci (15-20.YY). "VAKIF VE IKKTISAT" Temalı Vakıf Haftası bildirisi.

Yurdugüzel, O.T. (2017). Karma Sit Alanı Sınırları İçinde Fiziksel Ve Sosyal Katmanlaşmanın Belgelenmesi Ve Kentsel Koruma Bağlamında Değerlendirilmesi Iç̧in Bir Yöntem Araştırması: Ankara Örneği. Doktora Tezi, Gazi Üniversitesi Fen bilimleri Enstitüsü, Ankara.

URL-1: https://www.ankara.bel.tr Erişim tarihi: 30.03.2019.

URL-2: https://www.cekulvakfi.org.tr Erişim tarihi: 21.05.2019.

URL-3: http://www.ohu.edu.tr Erişim tarihi: 21.05.2019. 
URL-4: http://www.manisakulturturizm.gov.tr Erişim tarihi: 21.05.2019.

URL-5: https://www.google.com Erişim tarihi: 21.05.2019.

URL-6: https://www.tarsus.bel.tr Erişim tarihi: 11.06.2019.

URL-7: http://www.arkitera.com Erişim tarihi: 11.06.2019.

URL-8: https://www.kulturportali.gov.tr Erişim tarihi: 11.06.2019.

URL-9: https://www.trthaber.com Erişim tarihi: 11.06.2019.

URL-10: https://www.samsun.com.tr Erişim tarihi: 11.06.2019.

URL-11: http://www.habitat.org.tr Erişim tarihi: 11.06.2019.

URL-12: http://www.usakkulturturizm.gov.tr Erişim tarihi: 11.06.2019.

URL-13: https://tekirdagsehri.wordpress.com Erişim tarihi: 11.06.2019.

URL-14: http://www.afyonkultur.gov.tr Erişim tarihi: 11.06.2019.

URL-15: https://www.anadoluyugeziyorum.com Erişim tarihi: 11.06.2019.

URL-16: https://www.tripadvisor.com.tr Erişim tarihi: 11.06.2019.

URL-17: http://www.haber7.com Erişim tarihi: 11.06.2019. 